Jurnal Lakon, 8 (2) 2019

97-109

\title{
Tokoh Utama Tak Berpengharapan dalam Cerita Rakyat Indonesia
}

\author{
Hero of Unpromising Appearance in Indonesian Folklore
}

\section{IIT PURNAMA ASRI}

\author{
Program Studi Magister Kajian Sastra dan Budaya \\ Fakultas Ilmu Budaya Universitas Airlangga \\ Jl. Dharmawangsa Dalam Selatan, Surabaya 60286 \\ e-mail: iit.purnama.asri-2016@fib.unair.ac.id
}

\begin{abstract}
This research aims to explore how the hero of an unpromising appearance is told by Indonesian folklore. This research focuses on two folklores whose the main male characters are ugly men, namely Bujang Katak from Bangka Belitung and The Youngest Frog from Kei Island. The two main male characters in different stories are described through A. J. Greimas' theory. The focus of this research is the similarity of objects in the form of marriage with a princess and a different opponent, which is a condition from the king. The findings of this research are: 1) The object of the two stories is the same that is married to the king's daughter, which means the source of happiness for man is marriage. 2) The opponent of two stories, which is a condition from the king, shows that king and daughter, who marries Bujang Katak and The Youngest Frog, are materialistic.
\end{abstract}

Keywords: A. J. Greimas Theory, Indonesian Folklore, Marriage as the Source of Happiness

Abstrak: Penelitian ini bertujuan untuk menguak bagaimana tokoh utama yang tidak berpengharapan diceritakan dalam cerita rakyat Indonesia. Penelitian ini berfokus pada dua cerita rakyat dengan tokoh utama pria yang tidak rupawan yaitu Bujang Katak dari Bangka Belitung dan Si Bungsu Katak dari Pulau Kei. Dua karakter laki-laki utama dalam cerita dijelaskan melalui teori aktansial A. J. Greimas. Fokus dari penelitian ini adalah kesamaan objek dalam bentuk pernikahan dengan putri raja dan penentang yang berbeda yaitu persyaratan dari raja. Temuan dari penelitian ini meliputi: 1) Objek dari dua cerita adalah sama yaitu pernikahan dengan putri raja, yang berarti sumber kebahagiaan bagi pria adalah pernikahan; 2) Penentang pada kedua cerita yaitu persyaratan dari raja yang menunjukkan bahwa raja dan putrinya yang menikahi Bujang Katak dan Si Bungsu Katak adalah materialistis. Hal itu dapat dilihat dari persyaratan yang diajukan oleh raja bersifat sangat material dan sang putri tidak menolak persyaratan tersebut.

Kata-kata Kunci: Cerita Rakyat Indonesia, Pernikahan Sumber Kebahagiaan, Teori A. J. Greimas

\section{PENDAHULUAN}

Dalam cerita rakyat Indonesia, tidak semua tokoh utama (hero atau heroine) memiliki wajah yang rupawan, gagah, dan pintar. Ada beberapa cerita rakyat yang mengusung tema cerita dengan tokoh yang tidak beruntung seperti memiliki wajah buruk rupa. Tokoh tersebut seakan tidak memiliki harapan karena wujudnya yang tidak menguntungkan. Umumnya, tokoh cerita dengan hero of unpromising appearance akan menerima pengucilan dari masyarakat karena rupanya yang buruk. Bunanta (2011) dalam pengantar cerita Si Bungsu Katak mengatakan bahwa dongeng semacam ini di dalam daftar Motif Indeks

Jurnal Lakon: Kajian Sastra dan Budaya

e-ISSN: 2527-4899; p-ISSN 2252-8954 
Stith Thompson bernomor L 112 adalah tokoh lelaki atau perempuan yang tak berpengharapan karena wajah yang tak menguntungkan.

Cerita rakyat dengan tokoh utama yang memiliki rupa tak menguntungkan dapat ditemui dalam cerita rakyat Bujang Katak dari Bangka Belitung. Bujang Katak menceritakan mengenai seorang ibu yang menginginkan anak meski anaknya seekor katak. Keinginan ibu itupun dikabulkan sehingga saat mencuci baju di sungai dia menemukan seorang bayi laki-laki. Beranjak dewasa, Bujang Katak ingin menikah dengan putri raja namun permintaannya agak sulit dikabulkan karena perawakannya menyerupai katak.

Cerita tipikal yang mengusung katak sebagai seorang hero juga terdapat pada $S i$ Bungsu Katak, cerita rakyat dari Kepulauan Kei. Si Bungsu Katak adalah anak ketujuh dari tujuh bersaudara yang memiliki rupa seperti katak. Dia terlahir dengan wajah dan tubuh katak, padahal saudara lelakinya yang lain memiliki perawakan gagah dan tampan. Tidak ada yang mengetahui mengapa hal itu terjadi pada Si Bungsu Katak.

Saat beranjak dewasa, Si Bungsu Katak ingin mempersunting putri raja. Namun, penampilannya yang seperti katak membuat Si Bungsu Katak ditertawakan dan ditolak mentah-mentah oleh raja. Sama seperti Bujang Katak, Si Bungsu Katak pun berusaha untuk menikah dengan putri raja. Mereka berusaha dengan caranya sendiri untuk mewujudkan keinginan mereka menikah dengan putri raja.

Fenomena katak sebagai tokoh utama dalam cerita rakyat Bujang Katak dari Bangka Belitung dan Si Bungsu Katak dari Kepulauan Kei tentu memiliki maksud tersendiri. Tentu ada pertanyaan: mengapa harus katak yang menjadi hero of unpromising appearance dalam kedua cerita rakyat tersebut? Meski sama-sama mengusung katak sebagai tokoh utama yang memiliki rupa tidak menguntungkan, tetapi kedua cerita tersebut memiliki cara sendiri bagaimana mereka menceritakan tokoh utama katak. Oleh sebab itu, pembahasan ini berfokus bagaimana penceritaan tokoh utama katak yang ingin menikahi putri raja dalam kedua cerita rakyat Indonesia, yaitu Bujang Katak dan Si Bungsu Katak. Namun, sebelum memaparkan tata cerita kedua teks tersebut, berikut ini dipaparkan dahulu alasan mengapa kedua cerita dari pulau yang jauh memiliki tipikal sama.

\section{LANDASAN TEORI}

Tata cerita memiliki hubungan yang berbeda-beda. Setiap tokoh memiliki fungsi masing-masing dan menduduki beberapa peran. Hal ini disebabkan adanya relasi fungsi antar tokoh yang dapat membangun suatu cerita. Tata cerita yang memiliki hubungan yang berbeda-beda dapat diskemakan melalui aktan. Dalam teori Greimas (1983: 202), aktan dapat menggambarkan suatu fungsi yang menduduki beberapa peran. Berdasarkan peran tersebut, karakter tokoh dapat diamati. Perlu dicatat bahwa tidak semua tokoh memiliki fungsi dalam aktan dan tidak semua tokoh memiliki satu peran. Ada beberapa tokoh yang memiliki banyak peran dalam aktan.

Menurut Greimas (1983: 207), aktan dapat dikatakan sebagai sesuatu yang abstrak seperti cinta, kebebasan, atau tokoh. Aktan dapat dihubungkan melalui satuan sintaksis naratif yang unsur 
sintaksis tersebut memiliki fungsi tertentu. Setiap fungsi memiliki makna sendiri sebagai satuan cerita yang menerangkan tindakan yang membentuk narasi. Ada enam fungsi dalam aktan yang digagas Greimas (dalam Hebert, 2005: 63), antara lain subjek, objek, pengirim atau sender, penerima atau receiver, penolong atau helper, dan penentang atau opponent.

Aktan sebagai satuan naratif terkecil yang dikaitkan dengan satuan sintaksis naratif. Aktan memiliki fungsi tertentu yang menerangkan tindakan logis yang membentuk suatu narasi. Skema aktan dapat menggerakkan cerita sehingga menjadi penceritaan, yang diawali dengan permulaan, komplikasi, lalu penyelesaian. Model aktansial Greimas dapat digambarkan sebagai berikut:

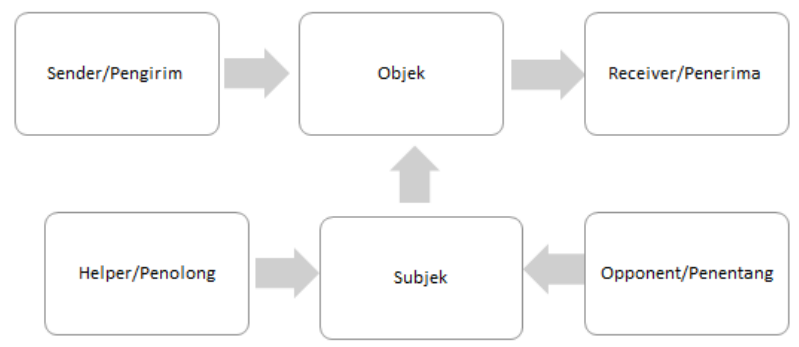

Gambar 1. Model aktansial Greimas

Keenam aktan yang sudah diklasifikasikan menempati posisi dan fungsinya masing-masing. Fungsi dari masing-masing aktan sebagai berikut:

1. Subjek memiliki peran utama dalam suatu cerita. Subjek dapat berupa tokoh utama yang mengarahkan jalannya cerita dan memiliki porsi besar di dalam suatu cerita.

2. Objek adalah tujuan dan keinginan yang ingin dicapai oleh subjek. Oleh sebab itu, objek bergantung pada objek karena menjadi bagian mengenai apa yang ingin dituju oleh subjek.

3. Pengirim atau sender yang menjadi penentu arah atau penggerak cerita yang dapat berupa ide di dalam narasi. Pada umumnya, pengirim atau sender tidak bergerak secara langsung.

4. Penerima atau receiver yaitu pihak yang diuntungkan saat subjek dapat mencapai apa yang dituju. Penerima dapat berfungsi sebagai pembawa nilai dari pengirim yang mengacu objek.

5. Penolong atau helper berfungsi untuk mendukung subjek dalam mencapai objek.

6. Penentang atau opponent berfungsi sebagai penghalang subjek untuk mencapai objek.

Aktansial yang dikemukakan oleh Greimas penting diketahui untuk memahami bagaimana penceritaan suatu narasi. Dengan mengetahui keenam aktan yang ada di dalam suatu cerita, peneliti dapat mengungkapkan makna yang terdapat di dalam cerita tersebut.

\section{METODE}

Metode yang digunakan di dalam penelitian ini yaitu pemikiran A. J. Greimas mengenai aktansial untuk menganalisis data berupa kutipan teks yang terdapat di dalam kedua cerita rakyat, Bujang Katak dan Si Bungsu Katak. Oleh sebab itu, penelitian ini menggunakan cara kerja analisis data dengan menentukan terlebih dahulu aktan-aktan di kedua cerita setelah 
melakukan pembacaan. Setelah itu, peneliti memaknai apa yang terdapat di dalam teks setelah mengetahui aktan-aktan yang sudah diidentifikasi. Kemudian, peneliti menarik simpulan setelah melakukan pemaknaan.

Penelitian ini menggunakan pendekatan kualitatif karena menggunakan data kebahasaan berupa kutipan di dalam teks kedua cerita. Dengan demikian, peneliti tidak menggunakan data statistik untuk menganalisis penelitian ini. Pendekatan kualitatif dilakukan di dalam penelitian ini karena objek material yang digunakan adalah teks cerita Bujang Katak dan Si Bungsu Katak, sedangkan objek formal pada penelitian ini yaitu teori aktansial A.J. Greimas.

\section{PEMBAHASAN}

\section{Kebudayaan Masyarakat Kepulauan Kei dan Bangka Belitung}

Indonesia memiliki keanekaragaman budaya dan cerita lisannya. Hal itu disebabkan Indonesia yang memiliki keanekaragaman suku bangsa, ras, dan agama. Keadaan tersebut membuat Indonesia menjadi kaya dengan cerita lisan yang di tahun 2000-an sudah mulai ditulis agar tidak punah.

Hal itu terjadi pada cerita Si Bungsu Katak dan Bujang Katak yang berawal dari cerita lisan kemudian ditulis untuk melestarikannya. Cerita Si Bungsu Katak yang berasal dari Kepulauan Kei, Maluku Tenggara, memiliki penceritaan yang hampir sama dengan cerita Bujang Katak yang berasal dari Bangka Belitung. Sebelum menjawab pertanyaan tersebut, sebaiknya diketahui terlebih dahulu bagaimana asalusul kebudayaan masyarakat Kepulauan Kei dan Bangka Belitung.
Kepulauan Kei adalah salah satu kepulauan yang ada di Kabupaten Maluku Tenggara, Provinsi Maluku dengan jumlah 66 buah pulau kecil. Kepulauan Kei terletak di bagian selatan Laut Arafura, di bagian barat Laut Banda dan Kepulauan Tanimbar, Papua bagian selatan dan wilayah Kota Tual di bagian utara Laut Banda dan bagian utara Kepulauan Tanimbar di bagian barat daya, serta Kepulauan Aru di bagian timur. Dilansir dari okezone (Riyani, 2017), Kepulauan Kei memiliki hubungan erat dengan masyarakat di Bali. Hubungan dengan masyarakat Bali ditelusuri dari cerita (Tom) dan tanda bukti (Tad) mengenai asal-usul masyarakat Kei.

Berdasarkan cerita yang dituturkan secara lisan dari generasi ke generasi, sebagian leluhur dari Kei berasal dari Bali. "Karena berdasarkan kepercayaan Kei, leluhur kami yang datang dari Bali datang ke Kei. Buktinya ada Hindu Bali. Masyarakat paling banyak di desa itu masyarakat Hindu," ujar Kepala Dinas Pariwisata Kabupaten Maluku Tenggara, Roy Rahajaan yang juga penduduk asli Maluku dalam konferensi pers Bali-Kei Archipelago Festival 2017 di Jakarta. Masuknya masyarakat Bali ke Kepulauan Kei tidak lepas dari Patih Gajah Mada yang ingin menyatukan wilayah nusantara ketika berkuasanya Raja Hayam Wuruk. Adanya pergolakan politik di Pulau Jawa, membuat masyarakat Bali berpindah ke Kepulauan Kei sehingga ikut mempengaruhi sosial budaya penduduk Kepulauan Kei, termasuk sastra lisannya.

Hal serupa terjadi di Bangka Belitung. Pulau Belitung atau Belitong memiliki kaitan dengan Pulau Bali. Konon, pada ribuan tahun silam, Belitung terletak di semenanjung Pulau Bali. Wilayah tersebut kemudian terpotong dan hanyut 
terbawa gelombang besar menuju ke utara, tepatnya di wilayah timur Sumatera. "Itu sebabnya dahulu orang menyebutkan dengan Belitong atau Bali yang terpotong," kata Bupati Belitung Timur, Basuri Purnama.

Keadaan tersebut membuat Belitung memiliki persamaan dengan Bali seperti segi sastra lisannya mengenai Pangeran Katak (Bali) dan Bujang Katak (Bangka Belitung). Bahkan, cerita tokoh utama katak yang terdapat pada cerita memiliki persamaan pula dengan cerita tokoh utama katak dari Kepulauan Kei. Dengan demikian, korelasi adanya persamaan cerita tokoh katak dari Kepulauan Kei dan Bangka Belitung disebabkan hubungan sosial budaya kedua pulau tersebut dengan Pulau Bali.

Tata Cerita Bujang Katak dan Si Bungsu Katak

Berdasarkan tata cerita menurut aktansial Greimas, aktansial Bujang Katak dapat digambarkan sebagai berikut:

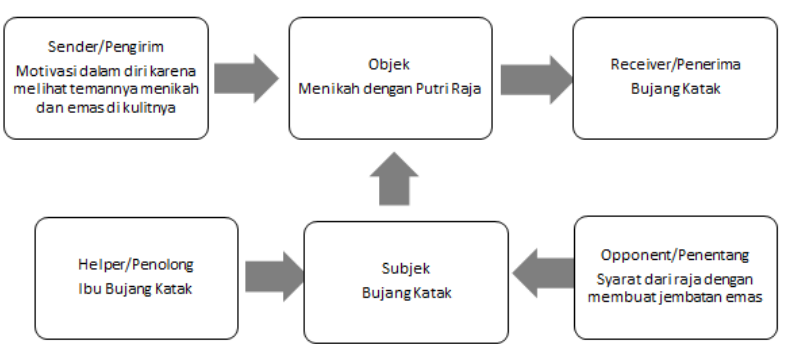

Gambar 2. Aktansial cerita Bujang Katak

Dari aktansial di atas, subjek cerita tersebut adalah Bujang Katak karena Bujang Katak adalah pelaku untuk mewujudkan objek yang dituju yaitu menikah dengan putri raja. Bujang Katak sebagai subjek untuk memperoleh objek dibantu oleh helper atau penolong yaitu Ibu Bujang Katak. Namun, subjek tidak serta merta dapat mewujudkan keinginannya karena adanya penentang atau opponent yaitu syarat dari raja dengan membuat jembatan emas agar dapat menikah dengan putrinya.

Sebelumnya, objek berupa menikah dengan putri raja terjadi akibat adanya sender atau pengirim yang berupa motivasi dalam diri karena melihat temannya menikah. Jika objek berupa menikah dengan putri raja terpenuhi, maka receiver atau penerima dari objek adalah Bujang Katak. Dalam artian, jika objek berupa menikah dengan putri raja terpenuhi, maka Bujang Katak yang diuntungkan karena Bujang Katak selain sebagai subjek juga sebagai penerima.

Supaya dapat dilihat perbedaan dan persamaan kedua cerita, berikut ini dipaparkan aktansial cerita Si Bungsu Katak sebagai berikut:

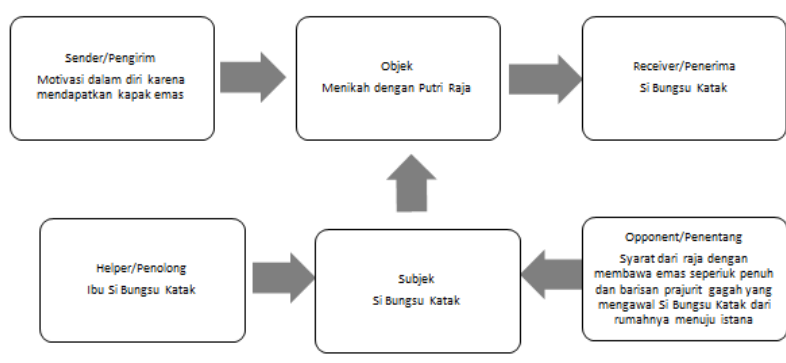

Gambar 3. Aktansial cerita Si Bungsu Katak

Berdasarkan aktansial di atas, subjek yang menjadi pelaku untuk mewujudkan objek adalah Si Bungsu Katak, sedangkan objek yang dituju oleh subjek adalah menikah dengan putri raja. Dalam mewujudkan keinginannya, subjek dibantu oleh helper atau penolong yaitu Ibu Si Bungsu Katak. Namun, subjek dalam mewujudkan misinya memiliki penentang atau opponent yaitu syarat dari raja dengan membawa emas seperiuk penuh dan barisan prajurit gagah yang mengawal $\mathrm{Si}$

Jurnal Lakon: Kajian Sastra dan Budaya 
Bungsu Katak dari rumahnya menuju istana.

Objek menikah dengan putri raja terjadi berkat adanya sender atau pengirim. Perlu digarisbawahi bahwa sender atau pengirim tidak harus tokoh namun suatu keadaan pun dapat menjadi sender. Dari cerita Si Bungsu Katak, sender yang melatarbelakangi adanya objek yaitu motivasi dalam diri Si Bungsu Katak karena mendapatkan kapak emas dari raksasa yang dikalahkannya sehingga dia menjadi kaya. Pertanyaan berikutnya, setelah objek diwujudkan, siapa yang diuntungkan atas objek tersebut? Dari aktansial di atas, tokoh yang diuntungkan karena menikah dengan putri raja adalah Si Bungsu Katak, sehingga receiver atau penerima dari aktansial cerita Si Bungsu Katak adalah Si Bungsu Katak.

Pemaparan tata cerita dari aktansial Bujang Katak dan Si Bungsu Katak dapat dicari persamaan dan perbedaannya melalui tabel di bawah ini:

\begin{tabular}{|c|c|c|c|c|}
\hline \multirow{2}{*}{ No } & \multicolumn{2}{|c|}{ Persamaan } & \multicolumn{2}{|c|}{ Perbedaan } \\
\hline & Bujang Katak & Si Bungsu Katak & Bujang Katak & Si Bungsu Katak \\
\hline 1. & $\begin{array}{l}\text { Subjek dalam } \\
\text { cerita adalah tokoh } \\
\text { utama, yaitu } \\
\text { Bujang Katak }\end{array}$ & $\begin{array}{l}\text { Subjek dalam } \\
\text { cerita adalah tokoh } \\
\text { utama, yaitu Si } \\
\text { Bungsu Katak }\end{array}$ & $\begin{array}{lr}\text { Sender } & \text { dalam } \\
\text { cerita } & \text { yaitu } \\
\text { motivasi dalam diri } & \text { karena melihat } \\
\text { temannya menikah }\end{array}$ & $\begin{array}{l}\text { Sender dalam } \\
\text { cerita } \\
\text { motivasi dalam diri } \\
\text { karena } \\
\text { mendapatkan } \\
\text { kapak emas dari } \\
\text { raksasa }\end{array}$ \\
\hline 2. & $\begin{array}{l}\text { Objek dalam cerita } \\
\text { adalah menikah } \\
\text { dengan putri raja }\end{array}$ & $\begin{array}{l}\text { Objek dalam cerita } \\
\text { adalah menikah } \\
\text { dengan putri raja }\end{array}$ & $\begin{array}{l}\text { Opponent dalam } \\
\text { cerita adalah } \\
\text { syarat dari raja } \\
\text { berupa membuat } \\
\text { jembatan emas }\end{array}$ & $\begin{array}{l}\text { Opponent dalam } \\
\text { cerita adalah } \\
\text { syarat dari raja } \\
\text { untuk membawa } \\
\text { seperiuk emas dan } \\
\text { barisan prajurit } \\
\text { yang gagah }\end{array}$ \\
\hline 3. & $\begin{array}{l}\text { Receiver dalam } \\
\text { cerita adalah tokoh } \\
\text { utama, yaitu } \\
\text { Bujang Katak }\end{array}$ & $\begin{array}{l}\text { Receiver dalam } \\
\text { cerita adalah tokoh } \\
\text { utama, yaitu Si } \\
\text { Bungsu Katak }\end{array}$ & & \\
\hline 4. & $\begin{array}{l}\text { Helper dalam cerita } \\
\text { yaitu ibu tokoh } \\
\text { utama }\end{array}$ & $\begin{array}{l}\text { Helper dalam cerita } \\
\text { yaitu ibu tokoh } \\
\text { utama }\end{array}$ & & \\
\hline
\end{tabular}

Table 1. Persamaan dan perbedaan Bujang Katak dan Si Bungsu Katak 
Persamaan dan perbedaan yang hadir dalam kedua cerita dan ditelisik melalui tabel di atas tentu memiliki makna. Karya sastra adalah objek estetik sehingga memiliki ruang untuk dilakukan pemaknaan. Jika karya sastra tidak dimaknai, maka dia adalah artefak. Oleh sebab itu, peran manusia sebagai pembaca karya sastra sangat penting karena manusia dapat memaknai karya sastra tersebut. Seperti pendapat Teeuw (1984: 191) yang mengatakan bahwa karya sastra adalah artefak yang dapat memiliki makna dan menjadi objek estetik bila diberikan makna oleh manusia sebagai pembaca. Oleh sebab itu, dalam bab selanjutnya dilakukan pemaknaan berdasarkan tata cerita kedua cerita yaitu Bujang Katak dan Si Bungsu Katak dan persamaan serta perbedaannya. Namun, fokus dari pemaknaan dari segi persamaan objek berupa menikah dengan putri raja dan perbedaan opponent yaitu syarat dari raja. Kedua fokus pemaknaan tersebut dapat mewakili karakteristik dari cerita bertema hero of unpromising appearance.

\section{Objek Dominan: Menikah dengan Putri} Raja

Stuart Hall (1997: 17-19)
mengemukakan bahwa pandangan
seseorang terhadap dunia dapat
direpresentasikan melalui bahasa yang dia
gunakan. Begitu pula dalam karya sastra.
Karya sastra dapat mempresentasikan bagaimana teks tersebut mewakili dunia melalui penceritaan yang dilakukan. Representasi tersebut dinamakan representasi. Representasi mental berkaitan mengenai peta konseptual yang ada di dalam kepala setiap orang. Representasi mental digunakan untuk menginterpretasi makna yang ditangkap oleh indera manusia. Hal itu disebabkan karena panca indera adalah jalan untuk memperoleh makna sehingga konsep dan gambar dapat diinterpretasikan melalui kata-kata. Dengan demikian, manusia dapat mengungkapkan sesuatu yang ada di dalam atau di luar otak mereka. Representasi mental masih berbentuk abstrak karena berdasarkan peta konsep pikiran masingmasing individu. Berdasarkan paparan dari Stuart Hall, makna apa yang terkandung dari teks dapat diinterpretasi melalui bahasa. Dalam teks sastra, makna tersebut dapat dilihat dari kutipan yang terdapat teks cerita tersebut.

Dari kedua cerita, Bujang Katak dan Si Bungsu Katak, memiliki persamaan tata cerita dilihat dari objeknya, yaitu menikah dengan putri raja. Hal itu dapat dilihat pada kutipan berikut.

Kini, Bujang Katak dan putri bungsu sudah menjadi suami istri. Mereka tinggal di rumah Bujang Katak. Meski demikian, jembatan emas mempermudah putri bungsu untuk mengunjungi ayah dan ibunya. Bujang Katak dan istrinya hidup bahagia selama-lamanya. (K., 2017: 31)

Di tempat upacara kesatria tampan tidak menemukan Putri Bungsu, karena itu ia segera kembali pulang. Ketika ia mencari-cari kulit kataknya Putri Bungsu muncul dan berkata: "Aku telah mengetahui rahasiamu dan kulit katakmu telah kubakar sebab aku tak mau kau kembali menjadi katak."

Sejak itu Si Bungsu Katak tetap menjadi manusia dan bersama Putri Bungsu ia hidup bahagia. Ia mengajak pula ibunya untuk tinggal bersamanya di istana. (Bunanta, 2011)

Bujang Katak dan Si Bungsu Katak akhirnya menikahi sang putri dan hidup

Jurnal Lakon: Kajian Sastra dan Budaya 
bahagia di istana. Sedikit berbeda dengan Bujang Katak yang tinggal di rumah Bujang Katak setelah pernikahan, Si Bungsu Katak dan putri tinggal di istana. Namun, keduanya sama-sama memiliki akhir bahwa pernikahan adalah tujuan utama dari cerita ini.

Hal itu bisa dilihat dari frasa "hidup bahagia" dan "hidup bahagia selamalamanya". Kata "selama-lamanya" menunjukkan sebuah akhir, sebuah pencapaian luar biasa dari hidup, dan sebuah titik akhir. Karena kata "selamalamanya" adalah titik akhir, maka pernikahan memiliki peran penting dalam cerita. Bila Si Bungsu Katak dan putri bungsu tidak menikah, maka cerita tersebut tidak akan berakhir bahagia. Berdasarkan kutipan, kebahagiaan Bujang Katak, Si Bungsu Katak, dan kedua ibu tokoh utama adalah pernikahan. Oleh sebab itu, pernikahan digambarkan sebagai sesuatu yang penting, titik pencapaian luar biasa dari hidup, dan sebuah titik akhir. Melalui penggambaran pernikahan menurut kutipan di atas, pernikahan dapat dimaknai sebagai prestasi tertinggi dalam kehidupan. Jika dalam cerita tersebut pernikahan dihapuskan, maka representasi mengenai "hidup bahagia" dan "hidup bahagia selamalamanya" tidak akan terjadi.

Hal ini menunjukkan bahwa pernikahan adalah sumber kebahagiaan bagi manusia. Apapun bentuk dari manusia itu, meski memiliki rupa tidak menguntungkan seperti Bujang Katak dan Si Bungsu Katak, namun pernikahan akan membawa mereka pada kebahagiaan. Bila kedua tokoh tersebut tidak menikah, maka tidak ada kebahagiaan yang terjadi. Oleh sebab itu, pentingnya pernikahan dalam kedua cerita ini menunjukkan bahwa pernikahan adalah tujuan hidup manusia karena pernikahan adalah sumber kebahagiaan bagi manusia.

Lalu muncul pertanyaan, mengapa Bujang Katak dan Si Bungsu Katak diceritakan menikah dengan putri raja? Sebelum menjawab pertanyaan tersebut perlu diketahui mengenai latar belakang Bujang Katak dan Si Bungsu Katak. Bujang Katak tinggal bersama janda yang tinggal sebatang kara. Janda tersebut tidak memiliki anak dan ia ingin dikaruniai seorang anak meski anak tersebut seperti katak.

Pada suatu hari, ada seorang ibu yang tinggal sebatang kara. Suaminya sudah lama meninggal, dan beliau tidak punya anak. Ibu itu amat menginginkan seorang anak. Dia ingin ada yang menemaninya di hari tua nanti. (K., 2017: 4)

Tidak berbeda dengan Bujang Katak, Si Bungsu Katak pun hanya memiliki seorang ibu dan tujuh saudara laki-laki. Mereka tinggal di dekat pantai dengan menggantungkan hidup dari berladang dan menangkap ikan.

Dahulu kala di negeri Seribu Pulau hiduplah seorang ibu dengan tujuh anak laki-lakinya. Anaknya yang bungsu berwujud seekor katak. Tidak ada yang tahu mengapa demikian. Oleh karena itu, ia dipanggil Si Bungsu Katak. Mereka hidup dari berladang dan menangkap ikan. (Bunanta, 2011)

Kondisi kehidupan antara Bujang Katak dan Si Bungsu Katak sama-sama berada di garis kemiskinan. Hal itu ditunjukkan dari kata "janda", "sebatang kara", "berladang", dan "menangkap ikan". Janda menunjukkan seorang wanita yang

Jurnal Lakon: Kajian Sastra dan Budaya 
tidak memiliki suami dan di dalam cerita digambarkan dengan sosok wanita tua renta. Sebarang kara menunjukkan kehidupan seorang diri tanpa sanak saudara. Berladang menunjukkan kegiatan serupa bertani yang dilakukan oleh kebanyakan masyarakat di desa, sedangkan menangkap ikan menunjukkan kegiatan yang dilakukan nelayan di daerah pesisir.

Fenomena melalui keterwakilan kata-kata tersebut menunjukkan bahwa kehidupan Bujang Katak dan Si Bungsu Katak kekurangan secara finansial. Mereka perlu bekerja keras untuk mencukupi kehidupan sehari-hari. Namun, dengan percaya diri, Bujang Katak dan Si Bungsu Katak berani melamar putri raja. Keadaan tersebut tentu menjadi tanda tanya besar karena secara logika tidak mungkin seorang tokoh yang berparas katak dan miskin percaya diri melamar putri raja. Karena itulah, mari simak kutipan di bawah ini.

Pagi harinya, Putri Bungsu mengatakan pada suaminya bahwa ia harus pergi lagi membantu penduduk, tetapi kali ini ia segera kembali lagi ke rumah dan bersembunyi di kamar untuk melihat apa yang terjadi.

Dilihatnya si Bungsu Katak sedang berganti wujud menanggalkan kulit kataknya. Ia menjadi kesatria tampan dan gagah. Kini putri tahu rahasia kesatria itu. Setelah kesatria itu pergi, cepat-cepat diambilnya kulit katak tadi dan dibakarnya. (Bunanta, 2011)

Dari kutipan di atas, Si Bungsu Katak ternyata seorang kesatria tampan dan gagah. Namun, Si Bungsu Katak tidak mengatakan bahwa dia sebenarnya seorang kesatria tampan dan gagah. Dia menyembunyikan hal itu pada semua orang, termasuk istrinya. Fenomena tersebut mewakili bahwa sesungguhnya $\mathrm{Si}$ Bungsu Katak bersembunyi di balik sosok katak untuk menyembunyikan kerupawanan dirinya, keadaan itu ditandai dengan kalimat "Si Bungsu Katak sedang berganti wujud menanggalkan kulit kataknya". Dia menghendaki secara sadar bahwa Si Bungsu Katak tidak ingin sosoknya yang rupawan tersebut diketahui orang lain. Namun, karena putri mengetahui rahasianya, maka putri membakar kulit katak Si Bungsu Katak supaya tidak bersembunyi lagi. Keadaan serupa Si Bungsu Katak juga dialami Bujang Katak.

Hingga, suatu malam dia bermimpi. Dalam mimpinya, dia mandi di sumur belakang rumahnya.

Usai mandi, seluruh kulit tubuhnya terkelupas. Bujang Katak menjadi pemuda tampan berkulit halus.

.... Bujang Katak mandi dengan hati-hati. Ternyata benar, kulit tubuhnya mengelupas! Bujang Katak segera berlari ke dalam kamar.

.... "Hei, siapa kamu?" Ibu melonjak kaget melihat ada pemuda tampan di hadapannya.

“Aku Bujang Katak, Bu.” (K., 2017: 1821)

Kutipan di atas menunjukkan bahwa Bujang Katak mimpi mandi di sumur belakang rumahnya. Selesai mandi, Bujang Katak menjadi pemuda tampan dan kulit kataknya mengelupas. Mimpi tersebut dilakukan oleh Bujang Katak sehingga Bujang Katak menjadi pemuda tampan. Adanya kata "mandi" yang menunjukkan referen lain berupa "tampan", "kulit mengelupas", dan "berkulit halus" menandakan bahwa Bujang Katak selama hidupnya, dia jarang menjaga kebersihan, seperti mandi, sehingga tubuhnya licin dan 
bentol-bentol seperti katak. Dapat dicurigai bahwa sebenarnya Bujang Katak tahu bahwa dirinya adalah pemuda tampan namun dia bersembunyi di balik kulit kataknya karena dia menghendaki agar orang lain tidak tahu rupanya yang rupawan.

Pada kutipan berikutnya, Ibu Bujang Katak kaget melihat sosok pemuda tampan di hadapannya, lalu Bujang Katak menceritakan pada Ibu bahwa dirinya adalah Bujang Katak. Kekagetan Ibu pada sosok Bujang Katak dapat menjadi alasan bahwa Bujang Katak selama ini menyembunyikan wujud wajahnya yang rupawan karena dari lahir ibunya melihat sosok katak dalam dirinya. Dengan demikian, Bujang Katak menyadari bahwa selama ini dia adalah pemuda tampan namun karena ibunya mengenal Bujang Katak sebagai katak sejak kecil, maka Bujang Katak sengaja menyembunyikan wajah rupawannya di balik sosok katak. Caranya adalah sengaja jarang mandi, bahkan tidak mandi, supaya wujud aslinya tidak diketahui.

Berdasarkan pemaparan di atas, mengenai objek kedua cerita yang sama, yaitu menikah dengan putri raja bermakna bahwa sumber kebahagiaan bagi manusia adalah pernikahan. Meski memiliki rupa tidak menguntungkan seperti Bujang Katak dan Si Bungsu Katak, namun pernikahan akan membawa seseorang pada kebahagiaan. Pernikahan digambarkan sebagai titik puncak dalam hidup, karena melalui pernikahan kebahagiaan dapat diraih.

\section{Mengenai pertanyaan "Mengapa} tokoh katak dalam kedua cerita harus menikah dengan putri raja?" Hal itu dapat dijawab karena kedua tokoh katak menyadari jika sebenarnya mereka adalah pemuda tampan dan gagah. Dengan menyadari bahwa mereka adalah pemuda tampan dan gagah, maka tokoh katak percaya diri untuk melamar putri raja. Bahkan, tokoh katak di kedua cerita memiliki dua pusaka, yaitu kapak emas pada Si Bungsu Katak dan Bujang Katak pada kulitnya (lihat aktansial). Namun, baik Bujang Katak dan Si Bungsu Katak, samasama menghendaki secara sadar bahwa dia ingin terlihat jelek di depan orang lain untuk menyembunyikan identitas perawakannya yang sebenarnya. Satu hal yang perlu digarisbawahi bahwa sebenarnya Bujang Katak dan Si Bungsu Katak bukan orang miskin. Mereka memiliki kekayaan yang memang disembunyikan oleh masing-masing tokoh. Oleh sebab itu, pertanyaan "Mengapa tokoh katak dalam kedua cerita harus menikah dengan putri raja?" karena kedua tokoh tersebut adalah seorang pemuda tampan, gagah, dan kaya yang menyamar menjadi sosok katak yang jelek dan miskin dengan kesadarannya sendiri agar mereka dapat diterima secara apa adanya di hadapan orang lain.

\section{Opponent yang Tak Sama: Syarat dari Raja}

Supaya dapat menikah dengan putri raja, Bujang Katak dan Si Bungsu Katak harus memenuhi persyaratan dari raja. Jika Bujang Katak dan Si Bungsu Katak tidak dapat memenuhi, maka mereka tidak dapat menikahi putrinya. Bujang katak harus membuat jembatan emas yang menghubungkan rumahnya dengan istana, sedangkan Si Bungsu Katak harus membawa seperiuk emas dan barisan prajurit yang gagah.

"Karena anakku adalah putri Raja, kamu harus membangun jembatan emas yang 
menghubungkan istana dengan rumahmu," pinta Raja.

Jembatan emas? Baiklah, aku akan membuatnya," sahut Bujang Katak. (K., 2017: 15)

"Aku akan menerima si Bungsu Katak menjadi menantuku bila dia datang sendiri menghadap ke istana. Pada hari kedatangannya harus ada barisan perajurit gagah berani lengkap dengan perisai berdiri sepanjang jalan mulai dari pondokmu sampai ke halaman istana. Selain itu anakmu harus menyediakan perhiasan yang indah dan mahal sebagai mas kawin seperiuk penuh. Pulanglah dan sampaikan pesanku ini pada anakmu," sabda raja kepada ibu si Bungsu Katak. (Bunanta, 2011)

Dari kutipan di atas, raja mengajukan syarat mengenai sesuatu yang bersifat material, yang ditandai dengan kata "jembatan emas", "perhiasan yang indah dan mahal", "perisai", dan "prajurit gagah berani". Secara logika, persyaratan tersebut terlalu berat diberikan kepada salah satu rakyatnya yang ingin mempersunting anak gadisnya. Padahal, raja dan putrinya tinggal di istana yang megah tanpa kekurangan. Namun, raja beranggapan bahwa syarat tersebut wajar diajukan untuk menikahi salah satu putrinya.

Raja yang lebih mementingkan sesuatu yang bersifat material kepada seseorang yang ingin melamar putrinya mempresentasikan bahwa raja adalah seseorang yang materialistis. Sisi materialistis raja tersebut diwakili dengan persyaratan berupa hal-hal yang bersifat duniawi seperti jembatan emas, perhiasan yang indah dan mahal, perisai, dan prajurit gagah berani. Meski kedua raja berbeda dalam memberikan persyaratan, namun keduanya sama-sama mementingkan hal duniawi. Kedua raja mementingkan kecukupan putrinya dari sisi finansial dan mereka khawatir jika Bujang Katak dan Si Bungsu Katak tidak dapat memenuhi kebutuhan materi masing-masing putrinya. Bagi raja, kebahagiaan seseorang dapat dilihat dari seberapa mampunya mereka dapat mencukupi hal-hal material.

Raja yang bersifat materialistis ini juga terwakili dengan sikap putrinya. Putri yang akan dilamar oleh Si Bungsu Katak menyetujui untuk dinikahi. Kali ini putri bungsu raja menaruh iba. Putri yang baik hati ini menerima pinangan si Bungsu Katak (Bunanta, 2011). Dari kutipan tersebut terlihat bahwa sang putri tidak menyukai $\mathrm{Si}$ Bungsu Katak. Sang putri hanya merasa iba. Tidak ada kekuatan cinta yang tulus dalam cerita Si Bungsu Katak. Atas dasar kasihan, sang putri mau menerima pinangan $\mathrm{Si}$ Bungsu Katak, namun penerimaan pinangan tersebut tidak cuma-cuma. Buktinya, saat raja mengajukan syarat kepada ibu Si Bungsu Katak, putri raja hanya diam. Dia tidak melakukan apapun. Keadaan itu menandakan bahwa putri raja bersedia dinikahi oleh Si Bungsu Katak asalkan Si Bungsu Katak dapat memenuhi persyaratan dari ayahnya yang materialistis. Dengan demikian, putri raja pun sebenarnya seseorang yang materialistis seperti ayahnya.

Raja pada Bujang Katak juga bersifat materialistis karena dia mengajukan persyaratan bersifat material berupa jembatan emas, padahal dia seorang raja yang memiliki segalanya. Putri raja yang dipinang oleh Bujang Katak pun tidak menolak atau melakukan sesuatu terhadap persyaratan yang diberikan oleh ayahnya

Jurnal Lakon: Kajian Sastra dan Budaya 
kepada Bujang Katak. Bahkan, dia bahagia dengan persyaratan itu.

"Jadi bagaimana? Kamu siap menikah dengan pemuda pilihanmu ini?" Putri bungsu tersipu dan mengangguk.

"Ya, Ayah. Dia sudah membuktikan kesungguhannya dengan mewujudkan jembatan emas ini." (K., 2017: 29)

Dari kutipan di atas, putri raja memiliki sifat seperti ayahnya, yaitu materialistis. Putri raja merasa senang ketika Bujang Katak mampu memenuhi persyaratan pembangunan jembatan emas. Padahal, pembuktian kesungguhan Bujang Katak pada sang putri raja tidak harus dengan membangun jembatan emas, misalnya dengan sesuatu yang lebih manusiawi seperti melindungi sang putri dari bahaya. Namun, kutipan di atas mempresentasikan bahwa pemikiran sang putri sama seperti ayahnya bahwa kebahagiaan dapat dilihat dari kecukupan kebutuhan materi.

\section{SIMPULAN}

Berdasarkan pembahasan yang telah dilakukan, dapat disimpulkan bahwa kemiripan cerita Bujang Katak yang berasal dari Bangka Belitung dan Si Bungsu Katak dari Kepulauan Kei karena adanya migrasi masyarakat Bali di kedua pulau tersebut akibat adanya konflik politik di Pulau Jawa yang mempengaruhi Pulau Bali. Migrasi masyarakat Bali membuat perubahan sosial dan budaya pada kedua pulau tersebut sehingga mempengaruhi pula pada sastra lisan mereka. Cerita dengan tokoh utama katak juga ada di Pulau Bali dengan judul Pangeran Katak. Objek kedua cerita sama, yaitu menikah dengan putri raja bermakna bahwa sumber kebahagiaan bagi manusia adalah pernikahan. Meski memiliki rupa tidak menguntungkan seperti Bujang Katak dan Si Bungsu Katak, namun pernikahan umumnya dianggap akan membawa seseorang pada kebahagiaan. Pernikahan digambarkan sebagai titik puncak dalam hidup, karena melalui pernikahan kebahagiaan dapat diraih. Tokoh katak dalam kedua cerita berniat menikahi putri raja karena kedua tokoh katak menyadari jika sebenarnya mereka adalah pemuda tampan dan gagah. Hal tersebut kemudian membangkitkan kepercayaan diri dari tokoh katak untuk melamar putri raja. Bahkan, tokoh katak di kedua cerita memiliki dua pusaka, yaitu kapak emas pada Si Bungsu Katak dan Bujang Katak pada kulitnya yang dapat meluruhkan emas. Namun, baik Bujang Katak dan Si Bungsu Katak, sama-sama menghendaki secara sadar bahwa dia ingin terlihat jelek di depan orang lain untuk menyembunyikan identitas perawakannya yang sebenarnya agar mereka dapat diterima secara apa adanya di hadapan orang lain. Raja dan putri yang menikah dengan Bujang Katak dan Si Bungsu Katak bersifat materialistis. Hal itu dapat dilihat dari persyaratan yang diajukan oleh sang raja bersifat sangat material dan putri tidak menolak persyaratan tersebut. Dalam artian, putri setuju dengan ayahnya bahwa kebutuhan material adalah kebutuhan penting bagi mereka yang harus dipenuhi.

\section{DAFTAR PUSTAKA}

Bunanta, Murti. 2011. Si Bungsu Katak. Jakarta: Grasindo.

Greimas, Algirdas Julien. 1983. Structural Semantics: An Attempt at a Method. Nebraska: University of Nebraska.

Hall, Stuart. 1997. Representation: Cultural Representations and Signifying Practices. London: SAGE Publications. 
Hebert, Louis. 2005. Tools for Text and Image Analysis An Introduction to Applied Semiotics. Quebec: University of Quebec.

JAN. "Legenda Bali Terpotong". nasional.kompas.com. 11 Agustus 2010. $15 \quad$ Desember 2017. <http://nasional.kompas.com/read/2 010/11/08/15112997/legenda.bali.te rpotong>

K., Dian. 2017. Bujang Katak. Jakarta: Bhuana Ilmu Populer.

Riyani, Utami Evi. “Terungkap! Sejarah Hubungan Bali dan Kepulauan Kei yang Tak Banyak Diketahui Orang". lifestyle.okezone.com. 21 Juli 2017. 15 Desember 2017. https://lifestyle.okezone.com/read/2 017/07/21/406/1741197/terungkap -sejarah-hubungan-bali-dankepulauan-kei-yang-tak-banyakdiketahui-orang

Teeuw, A. 1984. Membaca dan Menilai Sastra. Jakarta: Gramedia. 